\title{
STUDI PERBANDINGAN REGANGAN DI LAPISAN SUBGRADE AKIBAT BEBAN RODA KENDARAAN UNTUK JALAN RAYA KELAS I
}

\author{
Leonardo Lijuwardi ${ }^{1}$ dan Gregorius Sandjaja $S^{2}$ \\ ${ }^{1}$ Program Studi Sarjana Teknik Sipil, Universitas Tarumanagara, Jl. Letjen S. Parman No.1 Jakarta \\ leonardolijuwardi@gmail.com \\ ${ }^{2}$ Program Studi Sarjana Teknik Sipil, Universitas Tarumanagara, Jl. Letjen S. Parman No.1 Jakarta \\ gregoriussft@ft.untar.ac.id
}

Masuk: 30-06-2020, revisi: 06-07-2020, diterima untuk diterbitkan: 04-08-2020

\begin{abstract}
Multi-layer system theory is one of the concepts used to calculate the amount of strain and stress that occurs in the highway pavement system due to vehicle loads. The purpose of this study is to analyze the amount of strain that occurs on highways in Indonesia in the subgrade, especially in the subgrade position. The results with one-layer system calculations are very large because the modulus values of the subgrade layers are ignored and only review pavement thickness. As for calculations with the theory of two-layer systems, the results obtained are far greater than the one-layer system, due to the limitations of the graph to find the value of the ratio between thickness and large contact area. Calculations using the three-layer system theory are suggested theories for calculating strain because the value is much smaller than the theory of one-layer systems and two-layer systems. This is because this theory divides the calculated pavement layers into three layers, which is in accordance with the flexible pavement system which divides the pavement layers into three layers, so this calculation is the most ideal calculation because it approaches its original condition.
\end{abstract}

Keywords: multi-layer theory; strain; tension; subgrade

\begin{abstract}
ABSTRAK
Teori sistem lapis banyak merupakan salah satu konsep yang digunakan untuk memghitung besaran regangan dan tegangan yang terjadi pada sistem perkerasan jalan raya akibat beban kendaraan. Maksud dan tujuan dari penelitian ini adalah untuk menganalisis mengenai besaran regangan yang terjadi pada jalan raya di Indonesia pada lapisan tanah dasar khususnya di posisi permukaan tanah dasar. Hasil dengan perhitungan one-layer system sangat besar dikarenakan nilai modulus lapisan dari subgrade diabaikan dan hanya meninjau tebal perkerasan. Adapun untuk perhitungan dengan teori two-layers system, hasil yang diperoleh jauh lebih besar daripada one-layer system, yang disebabkan keterbatasan dari grafik untuk mencari nilai perbandingan antara ketebalan dan luas kontak yang besar. Perhitungan dengan teori three-layers system merupakan teori yang disarankan untuk menghitung regangan dikarenakan nilainya jauh lebih kecil dibandingkan dengan teori one-layer system dan two-layer systems. Hal ini dikarenakan teori ini membagi lapisan perkerasan yang dihitung menjadi tiga buah lapisan, yang sesuai dengan sistem perkerasan lentur yang membagi lapisan perkerasan menjadi tiga buah lapisan, sehingga perhitungan ini merupakan perhitungan yang paling ideal karena mendekati kondisi aslinya.
\end{abstract}

Kata kunci: teori lapis banyak; regangan; tegangan; tanah dasar

\section{PENDAHULUAN}

Sarana transportasi dan infrastruktur yang aman dan baik, khususnya jalan raya merupakan salah satu hal penting yang harus diusahakan dan dicapai di dalam dunia transportasi untuk menunjang perekonomian. Aktivitas perekonomian misalnya pendistribusian, kebutuhan untuk berpergian sangat dipengaruhi oleh jalan raya. Oleh karena itu, jalan raya merupakan salah satu aspek penting dalam kehidupan kita sehari - hari. Jalan raya harus didesain dan dirawat dengan baik, agar tercipta media dan sarana infrastruktur yang baik, aman dan nyaman terkait dengan transportasi darat.

Salah satu elemen penting pada kendaraan yang berhubungan dengan jalan raya adalah roda. Roda merupakan komponen pada kendaraan dimana roda merupakan komponen kendaraan untuk melintasi jalan raya. Dalam 
kaitannya dengan struktur jalan raya, roda merupakan komponen yang akan berperan menjadi media penyaluran beban kendaraan ke jalan. Roda menyebarkan tegangan dari sumbu kendaraan yang disalurkan melalui ban roda ke struktur lapisan jalan raya.

Apabila jalan mengalami kelebihan beban, maka terjadi kerusakan yang disebabkan oleh kelebihan beban terhadap struktur. Salah satunya adalah apabila kelebihan beban dan material perkerasan kurang baik, maka regangan dan tegangan yang diterima jalan raya sangat besar, sehingga jalan raya bias mengalami kerusakan, sehingga perlu adanya pengontrolan dan peninjauan terhadap nilai regangan dan tegangan yang terjadi pada perkerasan dan tanah dasar.

\section{Batasan masalah dalam penelitian ini antara lain:}

1. Jenis perkerasan yang dibahas pada kasus ini adalah perkerasan lentur pada jalan raya dengan kelas I.

2. Data tebal perkerasan yang digunakan diambil dan dikumpulkan dengan teknik dokumentasi.

3. Jenis besaran parameter perancangan perkerasan jalan raya, data lalu lintas akan diasumsikan.

4. Jenis tegangan dan regangan yang ditinjau pada kasus ini merupakan regangan yang terjadi hanya pada posisi vertikal, dimana regangan pada posisi radial dan tangensial tidak ditinjau.

Rumusan masalah yang akan dibahas pada penelitian ini adalah:

1. Berapa besar regangan yang terjadi pada lapisan subgrade pada perkerasan jalan kelas I di Indonesia?

2. Apakah jalan kelas I di Indonesia dapat mencapai umur rencana yang telah direncanakan dan memiliki tingkat keawetan yang baik?

Tujuan dari penelitian ini adalah:

1. Mengetahui besar regangan yang terjadi pada lapisan subgrade pada perkerasan jalan kelas I di Indonesia.

2. Mengetahui jalan kelas I di Indonesia apakah bisa mencapai umur rencana yang telah didesain dan direncanakan serta meninjau apakah jalan kelas I di Indonesia memiliki keawetan yang baik.

\section{Perkerasan jalan}

Menurut Hardiyatmo (2011) perkerasan jalan merupakan suatu bagian jalan raya yang diperkeras dengan agregat (Halus dan kasar) dan aspal atau semen (Portland cement) sebagai bahan pengikatnya sehingga terbentuk suatu lapisan konstruksi tertentu, yang memiliki ketebalan, kekuatan dan kekakuan, serta kestabilan tertentu agar mampu mendistribusikan beban lalu lintas yang berada diatasn perkerasan ke tanah dasar (Subgrade) secara aman. Kompenen material tersebut akan memberikan sokongan penting dari kapasitas struktur perkerasan.

Hardiyatmo (2011) menjelaskan bahwa fungsi utama dari suatu perkerasan sendiri adalah untuk menyebarkan atau mendistribusikan beban roda ke area permukaan tanah-dasar (Subgrade) yang lebih luas dibandingkan luas kontak roda dengan perkerasan. Adapun hal itu bertujuan untuk mengurangi dan mereduksi tegangan maksimum yang akan terjadi pada subgrade. Perkerasan harus memiliki kekuatan dalam menopang beban lalu-lintas.

\section{Perkerasan lentur}

Sukirman (1999) mengemukakan bahwa sistem perkerasan lentur (Flexible pavement) merupakan jenis suatu sistem perkerasan yang menggunakan aspal sebagai bahan pengikat perkerasannya. Lapisan-lapisan perkerasannya bersifat memikul dan menyebarkan beban lalu-lintas. Sukirman (1999) juga menegaskan bahwa secara sederhana perkerasan lentur merupakan campuran agregat batu pecah, pasir, material pengisi (Filler), dan aspal yang kemudian dihamparkan lalu dipadatkan.

Perkerasan lentur dirancang untuk melendut (berdeformasi) dan kembali lagi ke posisi semula bersama-sama dengan subgrade ketika kondisi pada saat menerima beban. Perancangan perkerasan lentur didasarkan pada teori elastis dan pegalaman lapangan. Menurut Hardiyatmo (2011), tujuan dari penggunaan teori elastis untuk menghitung perkerasan lentur adalah untuk menganalisis regangan dalam setiap lapisan perkerasan agar defleksi permanen tidak terjadi.

Sukirman (1999) mengemukakan bahwa sistem perkerasan lentur ini akan mengalami deformasi berupa lendutan atau lenturan bila perkerasan diberikan beban lalu lintas yang disebabkan oleh sifat penyebaran gaya akibat roda yang melintas. Ketika lapisan perkerasan diberikan beban, muatan beban yang akan diterima oleh masing-masing lapisan berbeda dan semakin kebawah semakin kecil. Gaya yang di terima masing-masing lapisan berbeda-beda dan akan semakin kecil. Lapisan permukaan harus mampu menerima seluruh jenis gaya yang bekerja, lapis pondasi atas menerima gaya vertikal dan getaran, sedangkan tanah dasar akan menerima gaya vertikal saja (Sukirman, 1999). 


\section{Tanah dasar (Subgrade)}

Tanah dasar (Subgrade) adalah permukaan tanah semula atau tanah asli, permukaan tanah galian atau permukaan tanah timbunan yang dipadatkan dan merupakan permukaan tanah dasar untuk perletakan bagian-bagian perkerasan lainnya. Pemadapatan yang baik diperoleh jika dilakuka pada kadar air optimum dan diusahakan kadar air tersebut konstan selama umur rencana. Hal ini dapat dicapai dengan perlengkapandan sistem drainase yang memenuhi syarat (Sukirman, 1999).

Beban kendaraan yang dilimpahkan ke lapisan perkerasan melalui roda-roda kendaraan selanjutnya disebarkan ke lapisan-lapisan dibawahnya dan terakhir diterima oleh tanah dasar. Kekuatan dan keawetan maupun tebal dari lapisan konstruksi perkerasan jalan sangat tergantung dari sifat-sifat dan daya dukung tanah dasar ini.

\section{Konsep sistem lapis banyak (multi layered systems theory)}

Dalam bukunya, Yoder (1975) mengemukakan bahwa dalam mencari solusi analitis terkait dengan tegangan dan regangan pada suatu lapisan perkerasan digunakan metode berupa persamaan sistem elastis lapis banyak.

Dikemukakan di dalam buku Yoder (1975), ada beberapa asumsi yang digunakan untuk menghitung solusi analitis terkait dengan besaran regangan dan tegangan serta defleksi pada suatu lapisan perkerasan jalan raya. Adapun terdapat beberapa asumsi yang digunakan untuk menyelesaikan persamaan tegangan, regangan dan defleksi tersebut antara lain sebagai berikut:

1. Properties material dari setiap lapisan diasumsikan sejenis.

2. Setiap lapisan perkerasan mempunyai nilai ketebalan yang berbatas, kecuali lapisan paling terbawah (Subgrade), dimana lapisan tersebut semuanya memiliki nilai tak terbatas ketebalannya di arah lateral.

3. Setiap lapisan diasumsikan isotropis.

4. Asumsi terjadinya gesekan penuh yang terjadi diantara setiap pemisahan lapisan.

5. Gaya geser yang terjadi pada lapisan permukaan tidak ada.

Penyelesaian tegangan ditentukan berdasarkan karakteristik dari parameter bahan untuk setiap lapisan perkerasan yaitu nilai angka Poisson dan modulus elastisitas.

\section{Luas bidang kontak}

Dalam menyelesaikan luas bidang kontak, Yoder (1975) dalam mengemukakan cara untuk menghitung dan menemukan luas bidang kontak. Adapun luas bidang kontak antara roda kendaraan dan lapisan permukaan bisa dicari dengan menggunakan rumus berikut.

$$
a=\sqrt{\frac{P}{p \pi}}
$$

dengan $\mathrm{a}=$ Besaran luas bidang kontak antara roda dengan lapisan permukaan $[\mathrm{m}], \mathrm{P}=$ Besaran berat beban sumbu kendaraan $(\mathrm{N}), \mathrm{p}=$ Besaran tekanan roda kendaraan $\left(\mathrm{N} / \mathrm{m}^{2}\right)$.

\section{Teori sistem satu lapisan (one-layer system theory)}

Ahlvin dan Uleri (1962) di dalam buku Yoder (1975) mengemukakan penyelesaian untuk beban merata di permukaan suatu massa yang semi terbatas. Adapun untuk penyelesaiannya menggunakan parameter bahan berupa modulus elastisitas dan angka poisson. Adapun rumus yang digunakan untuk mengitung persamaan elastis besaran regangan yang terjadi pada satu lapisan perkerasan adalah sebagai berikut:

$$
\begin{gathered}
\sigma z=p[A+B] \\
\varepsilon Z=(p(1+\mu)) / E[(1-2 \mu) A+B]
\end{gathered}
$$

dengan $\sigma z=$ Tegangan vertikal $\left[\mathrm{N} / \mathrm{m}^{2}\right], \varepsilon z=$ Regangan vertikal [Strain], $\mathrm{p}=$ Besaran beban roda $(\mathrm{MPa}), \mathrm{E}=$ Modulus elastisitas perkerasan (MPa), $\mu=$ Angka Poisson tanah, A, B = Koefisien fungsi dari tabel penyelesaian Ahlvin dan Foster.

\section{Teori sistem dua lapisan (two-layers system)}

Dalam penyelesaian dengan teori Two-Layer System, terdapat asumsi penting tertentu yang dibuat mengenai kondisi syarat batas dan kontinuitas. Terkait dengan bahan material pada lapisan perkerasan diasumsikan sejenis (Homogen), isotropis dan elastis. Pada lapisan permukaan (Surface) diasumsikan tak terbatas dalam arah lateral hingga mencapai kedalaman terbatas di lapisan yang mendasarinya (Lapisan subgrade). Untuk lapisan yang mendasarinya, lapisan tanah dasar (Subgrade) nilainya diasumsikan tak terbatas baik di kedua arah, secara vertikal 
dan horizontal. Adapun mengenai syarat kondisi batas dan kontinuitas membutuhkan lapisan dalam suatu kontak yang kontinu dan lapisan permukaan (Surface) harus bebas dari tegangan normal dan geser di luar area yang dimuat oleh beban roda kendaraan.

Burmister di dalam buku Yoder (1975) mengemukakan bahwa besaran nilai tegangan dan defleksi (Lendutan) yang didapat tergantung daripada perbandingan dari nilai kekuatan antar lapisan, dimana kekuatan pada lapisan digambarkan dengan nilai dari modulus elastisitas lapisan perkerasan yang digambarkan dengan rasio E1/E2 dimana E1 merupakan nilai dari idealisasi modulus elastisitas lapisan perkerasan dan E2 merupakan nilai dari modulus elastisitas pada lapisan subgrade atau tanah dasar. Burmister di dalam jurnal Highway Research Board Bulletin 177 pada buku Yoder (1975) mengemukakan suatu grafik yang bisa digunakan unruk mencari besaran tegangan vertikal dibawah suatu lapisan yang dibebani oleh beban pada sistem perkerasan dengan teori two-layers system. Berikut ini adalah grafik dari Burmister yang dimuat di dalam jurnal Highway Research Board Bulletin 177.

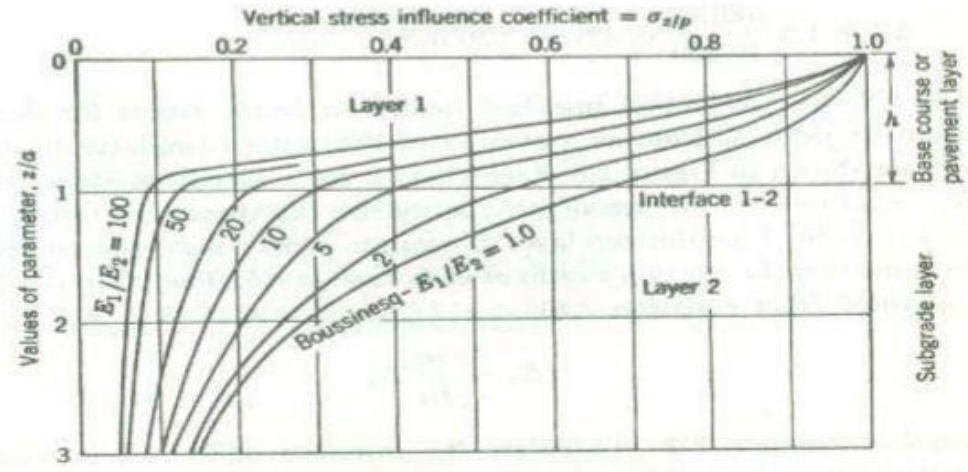

Gambar 1. Grafik burmister untuk mencari besaran pengaruh nilai tegangan vertikal dengan teori two-tayer systems (Yoder,1975)

\section{Teori sistem tiga lapisan (three-layers system)}

Yoder (1975) mengemukakan di dalam bukunya bahwa dalam perkembangannya, teori yang dicetuskan oleh Burmister memberikan penyelesaian dan solusi analitis untuk tegangan dan lendutan di dalam sistem elastis dua dan tiga lapisan (Two-Layer Systems dan Three-Layer Systems).

Solusi dari besaran nilai tegangan vertikal telah diperoleh oleh Peattie dan ditunjukkan dalam bentuk grafik yang akan tertera pada lampiran. Solusi tegangan horizontal telah diperoleh dari penelitian Jones dan ditunjukkan dalam bentuk grafik yang akan dimuat pada lampiran. Nilai-nilai tegangan sepanjang dengan sumbu simetri dari satu beban. Perlu dicatat bahwa angka dan tabel telah dikembangkan untuk rasio poisson 0,5 untuk semua lapisan. Konvensi tanda positif untuk kompresi. Sementara interpolasi faktor-faktor stres diperlukan untuk banyak solusi masalah, tidak ada ekstrapolasi yang diizinkan (Yoder,1975).

Dalam mencari tegangan vertikal dengan grafik maupun dengan tabel tabulasi untuk mencari tegangan horizontal dicari menggunakan rumus berikut.

$$
\begin{aligned}
k 1 \text { atau } K 1 & =\frac{E 1}{E 2} \\
k 2 \text { atau } K 2 & =\frac{E 2}{E 3} \\
\text { a1 atau } A & =\frac{a}{h 2} \\
H & =\frac{h 1}{h 2}
\end{aligned}
$$

dengan $\mathrm{k} 1$ atau $\mathrm{K} 1$ = Parameter rasio E1/E2, k2 atau K2 = Parameter rasio E2/E3, a1 atau A = Parameter rasio luas kontak dengan total tebal base dan subbase, $\mathrm{H}=$ Parameter rasio surface dengan total tebal base dan subbase, E1 = Modulus elastisitas perkerasan idealisasi surface (Three-Layers Systems) (MPa), E2 = Modulus elastisitas perkerasan idealisasi base dan subbase (Three-Layers Systems) (MPa), E3 = Modulus elastisitas tanah dasar atau subgrade $(\mathrm{MPa}), \mathrm{A}=$ Luas bidang kontak antara roda dengan lapisan permukaan $(\mathrm{m}), \mathrm{h} 1=$ Tebal lapisan surface (m), h2 = Tebal lapisan base dan subbase (m). 
Kombinasi nilai yang tersedia untuk mencari tegangan vertikal dengan menggunakan grafik Peattie adalah sebagai berikut untuk nilai k1 (K1) terdiri dari 0.2, 2.0, 20.0 dan 200.0. Untuk nilai k2 (K2) terdiri dari 0.2, 2.0, 20.0 dan 200.0. Adapun a1 (A) nilainya terdiri dari 0.1, 0.2, 0.4, 0.8, 1.6 dan 3.2. Sedangkan, untuk parameter H yaitu 0.125 , $0.25,0.5,1.0,2.0,4.0$ dan 8.0. Apabila nilai dari parameter tersebut tidak tertera pada grafik untuk mencari faktor nilai tegangan vertikal, maka dapat dicari dengan dilakukan metode interpolasi nilai kedua grafik.

Dengan diperolehnya faktor nilai dari tegangan vertikal dengan menggunakan niali $\mathrm{K} 1$, $\mathrm{K} 2$ dan $\mathrm{H}$ dari sistem perkerasan yang diplot grafik yang dikembangkan Peattie, nilai dari tegangan vertikal bisa dicari. Kemudian, setelah didapatkan faktor nilai dari tegangan vertikal, tegangan vertikal dicari dengan rumus sebagai berikut.

$$
\begin{aligned}
& \sigma z 1=Z Z 1 . P \\
& \sigma z 2=Z Z 2 . P
\end{aligned}
$$

dengan $\sigma z 1=$ Tegangan Vertikal di lapisan surface $\left[\mathrm{N} / \mathrm{m}^{2}\right], \sigma z 2=$ Tegangan Vertikal di lapisan base dan subbase $\left[\mathrm{N} / \mathrm{m}^{2}\right], \mathrm{P}=$ Besaran beban tegangan roda kendaraan $\left(\mathrm{N} / \mathrm{m}^{2}\right), \mathrm{ZZ1}=$ Faktor nilai untuk posisi surface dengan grafik Peattie, ZZ2 = Faktor nilai untuk posisi base dan subbase dengan grafik Peattie.

Untuk mencari tegangan horizontal dapat diperoleh dengan mencari faktor nilai dari tegangan horizontal denngan mengunakan parameter nilai dari $\mathrm{K} 1, \mathrm{~K} 2$, a1 dan $\mathrm{H}$ dari sistem perkerasan yang kemudian diplot pada tabel tabulasi yang dikembangkan oleh Jones. Tegangan horizontal dicari dengan rumus sebagai berikut.

$$
\begin{gathered}
\sigma z 1-\sigma r 1=[Z Z 1-R R 1] . P \\
\sigma z 2-\sigma r 2=[Z Z 2-R R 2] \cdot P \\
\sigma z 2-\sigma r 3=[Z Z 2-R R 3] \cdot P
\end{gathered}
$$

dengan $\sigma r 1=$ Tegangan Horizontal di lapisan surface $\left[\mathrm{N} / \mathrm{m}^{2}\right]$, $\sigma r 2=$ Tegangan Horizontal di lapisan base dan subbase $\left[\mathrm{N} / \mathrm{m}^{2}\right], \sigma \mathrm{r} 3=$ Tegangan Horizontal di lapisan subgrade $\left[\mathrm{N} / \mathrm{m}^{2}\right], \sigma \mathrm{z} 1=$ Tegangan Vertikal di lapisan surface $\left(\mathrm{N} / \mathrm{m}^{2}\right), \sigma \mathrm{z} 12=$ Tegangan Vertikal di lapisan base dan subbase $\left(\mathrm{N} / \mathrm{m}^{2}\right), \mathrm{P}=$ Besaran beban tegangan roda kendaraan $\left(\mathrm{N} / \mathrm{m}^{2}\right),[\mathrm{ZZ1}-\mathrm{RR} 1]=$ Faktor nilai posisi surface dengan tabel Jones , [ZZ2 $\left.-\mathrm{RR} 2\right]=$ Faktor nilai posisi base dan subbase dengan tabel Jones, [ZZ2 - RR3] = Faktor nilai posisi subgrade dengan tabel Jones.

Berdasarkan persamaan diatas, dijelaskan bahwa untuk memperoleh nilai tegangan horizontal dibutuhkan nilai tegangan vertikal. Oleh karena itu, dibutuhkan perhitungan dari tegangan vertikal. Karena analisis tegangan pada perkerasan ini sifatnya simetris, maka untuk beberapa jenis regangan dapat dihitung dari tegangan yang dihitung serta persamaan regangan. Maksudnya, apabila nilai dari satu layer diketahui, maka nilai tegangan dan regangan pada layer lainnya bisa dicari (Yoder,1975).

Terkait dengan paragraf sebelumnya, Yoder (1975) dalam bukunya mengemukakan cara untuk mencari regangan. Karena sifat dari analisis regangan dan tegangan yang simetris, maka beberapa nilai regangan pada suatu titik posisi bisa dihitung dari nilai tegangan yang dihitung berdasarkan persamaan - persamaan di atas dengan rumus regangan. Adapun rumus dari regangan untuk teori Three-Layers System ini adalah sebagai berikut.

$$
\varepsilon r 1=\frac{\sigma r 1}{E 1}-\mu 1 \frac{\sigma t 1}{E 1}-\mu 1 \frac{\sigma z 1}{E 1}
$$

dengan $\varepsilon r 1$ = Regangan Vertikal pada lapisan 1, lapisan surface [Strain], or1 = Tegangan Horizontal pada lapisan 1, lapisan surface $\left(\mathrm{N} / \mathrm{m}^{2}\right), \sigma t 1=$ Tegangan Vertikal pada lapisan 1, lapisan surface $\left(\mathrm{N} / \mathrm{m}^{2}\right), \sigma z 1=$ Tegangan Vertikal pada lapisan 1, lapisan surface $\left(\mathrm{N} / \mathrm{m}^{2}\right), \mathrm{E} 1=$ Modulus elastisitas lapisan 1 , lapisan surface $(\mathrm{MPa}), \mu 1=$ Angka Poisson lapisan 1, lapisan surface.

Yoder (1975) mengemukakan bahwa berdasarkan contoh persamaan di atas, dijelaskan bahwa apabila kita mengetahui nilai tegangan horizontal dan vertikal, maka kita bisa mencari nilai regangan vertikal. Selain itu, karena sifat analisis teori ini yang simetris maka regangan vertikal bisa dicari, baik di posisi layer 1, 2, bahkan di posisi layer 3, dengan kata lain posisi subgrade.

\section{Penelitian terdahulu mengenai regangan pada subgrade}

Untuk desain perkerasan yang tahan lama, regangan tarik yang membatasi di bagian bawah lapisan aspal serta tegangan tekan yang membatasi atau tegangan pada bagian atas tanah dasar dapat dicapai dengan cara memilih ketebalan dan bahan yang sesuai untuk lapisan perkerasan. 
Penelitian di proyek Strategic Highway Research Program 2 R23, Jackson et al. (2012) berupa pedoman ketebalan yang dikembangkan untuk desain perkerasan aspal tahan lama (30 hingga 50 tahun) di Amerika Serikat dimana pengembangan dilakukan berdasarkan pendekatan regangan terbatas untuk berbagai skenarioyang mensimulasikan kondisi lapangan ditemukan di lima lokasi yang representatif di A.S. Nilai minimum untuk ketebalan perkerasan adalah 5.5 inci dan ketebalan maksimum 14.0 inci yang direkomendasikan untuk perkerasan yang memiliki umur panjang. Selain itu, hal itu tergantung pada kondisi desain termasuk pembebanan lalu lintas dan kekakuan.

Secara historis, perkerasan yang tahan lama telah dirancang untuk memiliki regangan tarik di bagian bawah dari lapisan AC (Permukaan) di bawah FEL-nya sehingga struktur akan memiliki umur kelelahan yang tak terbatas. Selain itu, regangan vertikal di bagian atas tanah dasar diperiksa untuk memastikan bahwa itu di bawah yang ditentukan sebelumnya batas untuk mencegah rutting secara struktural. Batas daya tahan kelelahan yang digunakan di desain perkerasan yang memiiki umur panjang dan tahan lama biasanya ditentukan dari uji keletihan laboratorium dan memiliki besaran berkisar dari perkiraan awal 70 mikrostrain (Monismith, 1972) hingga nilai perkiraan lebih baru hingga 200 mikrostrain (Prowell et al., 2010). Nilai 200 mikrostrain telah diusulkan untuk batas regangan tekan vertikal oleh Monismith et al. (2004).

Monismith et al (2004) mengusulkan nilai dari batas nilai regangan vertikal untuk perkerasan jalan, yaitu 200 mikrostrain. Mereka menyarankan bahwa regangan vertikal yang dihitung di bagian atas tanah dasar (Subgrade) harus dijaga di bawah nilai ini untuk mencegah kerusakan berupa alur struktural. Pendekatan ini tidak hanya direkomendasikan oleh Monismith et al (2004), namun juga direkomendasikan oleh Walubita et al (2008).

Namun, alih - alih membatasi nilai dari regangan vertikal, Bejarano dan Thompson (2001) mengusulkan cara lain, yaitu pengendalian tegangan vertikal melalui rasio tegangan vertikal di bagian atas tanah dasar ke yang tidak terbatas kuat tekan tanah, disebut sebagai rasio tegangan tanah dasar. Mereka merekomendasikan menggunakan rasio tegangan tanah dasar 0.42 untuk tujuan desain.

Penelitian besarnya perkiraan regangan pada permukaan tanah dasar (subgrade) telah dilakukan di laboratorium dengan memadatkan tanah pada kondisi di sekitar kadar air optimum dan kemudian tanah yang sudah dipadatkan tersebut diuji pada alat uji desak bebas untuk meperkirakan besarnya regangan yang dapat terjadi di permukaan tanah dasar (Sentosa, 2014). Pada penelitian tersebut hasil regangan permukaan tanah dasar dalam kondisi elastis $(\leq$ $200 \mu \varepsilon$ s, microstrain) yang diperoleh dari uji desak bebas di laboratorium dibandingkan dengan perkiraan regangan yang dapat terjadi akibat beban roda kendaraan yang menyebabkan terjadinya teganga-tegangan pada lapisan perkerasan sampai mencapai permukaan tanah dasar.

\section{METODE PENELITIAN}

Metodologi yang digunakan dalam penelitian ini adalah studi literatur yang dilakukan dengan cara membandingkan antara besaran regangan yang terjadi pada lapisan tanah dasar (Subgrade) di jalan raya kelas I dengan metode perhitungan konvensional dengan parameter data yang diasumsikan dan didokumentasikan berdasarkan kondisi jalan kelas I di Indonesia jalan raya kelas I di Indonesia dengan teori untuk menghitung regangan dan tegangan pada sistem perkerasan lapis banyak (Multi Layered-Systems Theory).

Adapun data umum dan asumsi yang digunakan dalam penelitian ini adalah data kendaraan dan parameter perkerasan lentur jalan raya. Data kendaraan yang digunakan pada kasus ini terdapat 2 macam, yaitu besarnya berat sumbu kendaraan dan besaran tekanan roda kendaraan yang berperan sebagai beban pada struktur perkerasan lentur jalan raya. Besarnya nilai dari tekanan roda dan beban sumbu kendaraan diambil dan diasumsikan dari jenis kendaraan terberat yang melintas pada jalan raya kelas I di Indonesia. Adapun jenis tipe kendaraan yang diambil adalah jenis truk trailer. Untuk data mengenai parameter perkerasan lentur jalan raya, data ini diambil dari literatur penelitian - penelitian terdahulu yang memuat tentang berbagai perkerasan jalan raya kelas I di Indonesia. Data karakteristik perkerasan lentur yang diambil pada kasus ini antara lain adalah ketebalan dari tiap - tiap lapisan perkerasan jalan, total ketebalan perkerasan jalan raya, jenis material perkerasan jalan dan besaran nilai modulus elastisitas dari lapisan perkerasan jalan raya dan tanah dasar.

Adapun mengenai data - data jalan raya yang akan digunakan untuk penelitian ini adalah sebagai berikut:

1. Jalan Lingkar Selatan Provinsi Jawa Timur, dari penelitian Oetomo (2013), selanjutnya disebut sebagai jalan A.

2. Jalan Tol Jakarta-Cikampek, dari penelitian Hariyadi dan Rulhendri (2013), selanjutnya disebut sebagai jalan B.

3. Jalan di daerah Pekanbaru, Riau, dari penelitian Shalahuddin, selanjutnya disebut sebagai jalan C.

4. Jalan Mojoagung, Jawa Timur dari penelitian Nurahmi (2013), selanjutnya disebut sebagai jalan D.

5. Jalan Middle Ringroad Kota Makassar, dari penelitian Salim (2020), selanjutnya disebut sebagai jalan E. 
Alur atau tahapan dari penelitian ini tertera dalam bentuk diagram pada Gambar 1.

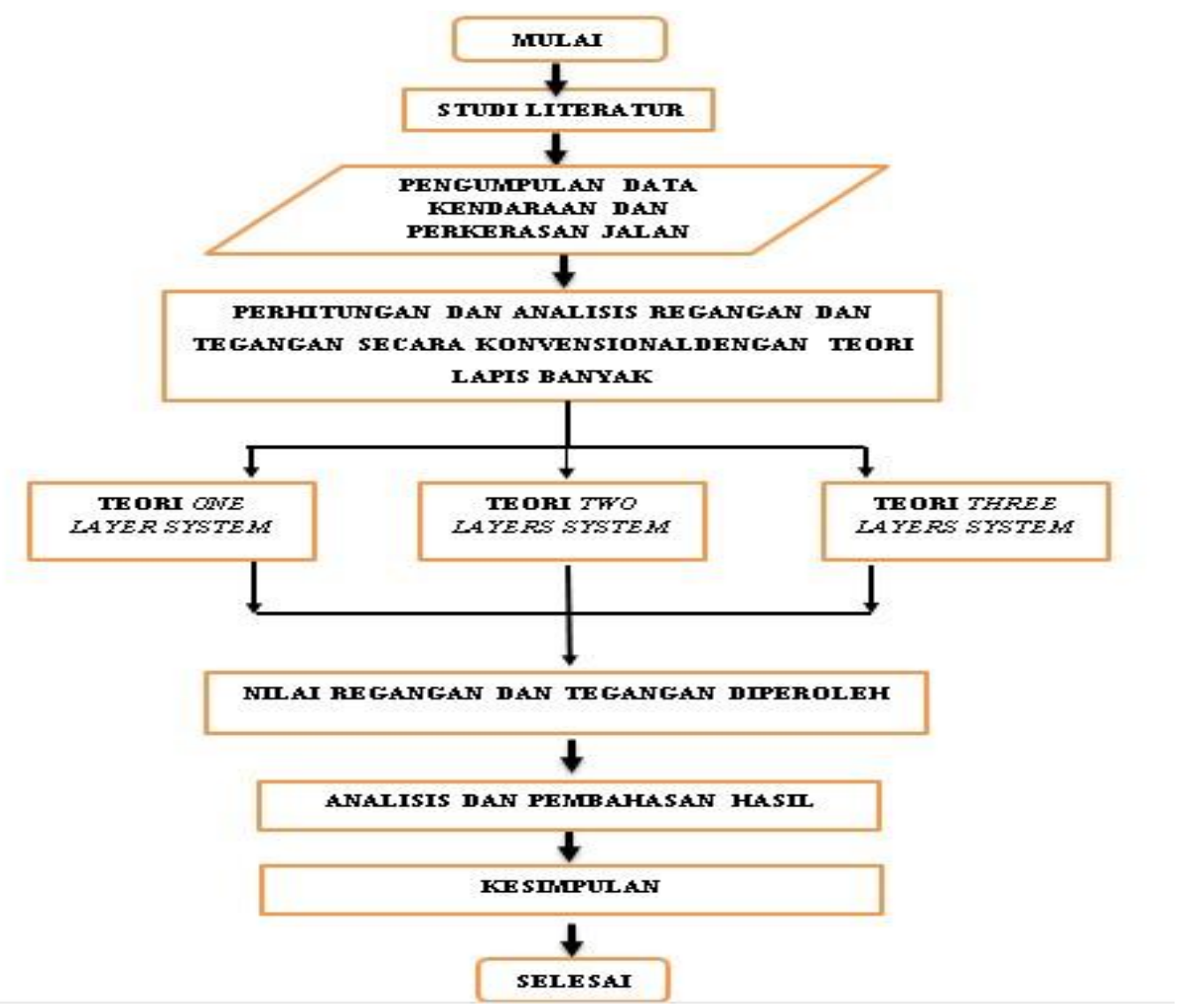

Gambar 2. Diagram alur penelitian

\section{HASIL DAN PEMBAHASAN}

\section{Data umum beban kendaraan}

Dalam penelitian ini, adapun mengenai jenis data kendaraan yang digunakan adalah besaran tekanan angin pada roda kendaraan dan berat sumbu kendaraan yang digunakan untuk menghitung luas kontak roda kendaraan terhadap lapisan permukaan perkerasan jalan raya yang akan digunakan untuk menghitung besaran tegangan dan regangan terhadap lapisan tanah subgrade. Adapun dalam perhitungan kali ini jenis kendaraan yang digunakan untuk perhitungan adalah jenis kendaraan truk trailer. Hal ini dikarenakan diasumsikan regangan terbesar yang terjadi pada jalan raya merupakan regangan yang terjadi akibat efek pembebanan dari melintasnya kendaraan yang terberat.

Berikut adalah nilai yang digunakan dalam perhitungan luas kontak kendaraan. Catatan: Diasumsikan berdasarkan kendaraan truk trailer umum.

- P $($ Besaran beban sumbu kendaraan $)=10$ Ton $=98.0665 \mathrm{KN}$ (Berdasarkan UU No. 22 tahun 2009)

- $\mathrm{p}($ Besaran tekanan roda kendaraan $)=100 \mathrm{Psi}=689.476 \mathrm{kPa}($ Tekanan angin roda trailer $)$

Perhitungan luas kontak roda kendaraan dihitung dengan rumus berikut.

$a=\sqrt{\frac{P}{p \pi}}=\sqrt{\frac{98.0665}{689.476 \pi}}=0.1504565 \mathrm{~m}$

Diperoleh besaran luas kontak roda kendaraan terhadap lapisan surface sebesar $0.1505 \mathrm{~m}$.

\section{Perhitungan besaran regangan}

Berikut ini adalah data umum yang akan dianalisis mengenai jalan yang akan dianalisis besaran regangannya, yaitu jalan kelas I di Indonesia. 
Tabel 1. Data jalan kelas I yang akan dianalisis besaran regangannya

\begin{tabular}{|c|c|c|c|c|c|c|}
\hline \multicolumn{2}{|c|}{ Parameter } & \multirow{2}{*}{$\begin{array}{c}\begin{array}{c}\text { Jalan A } \\
\text { (Oetomo,2013) }\end{array} \\
10\end{array}$} & \multirow{2}{*}{$\begin{array}{c}\text { Jalan B } \\
\text { (Hariyadi dan } \\
\text { Rulhendri ,2013) } \\
20\end{array}$} & \multirow{2}{*}{$\begin{array}{c}\text { Jalan C } \\
\text { (Shalahuddin) } \\
5,75\end{array}$} & \multirow{2}{*}{$\begin{array}{c}\text { Jalan D } \\
\text { (Nurahmi ,2013) } \\
13\end{array}$} & \multirow{2}{*}{$\begin{array}{c}\begin{array}{c}\text { Jalan E } \\
(\text { Salim,2020) }\end{array} \\
9\end{array}$} \\
\hline Ketebalan & Surface & & & & & \\
\hline Perkerasan & Base & 25 & 25 & 6,9 & 20 & 7,5 \\
\hline dalam $\mathrm{cm}$ & Subbase & 50 & 30 & 40 & 31 & 15 \\
\hline \multirow{3}{*}{$\begin{array}{c}\text { Jenis } \\
\text { Material } \\
\text { Perkerasan }\end{array}$} & Surface & Laston & AC/ATB & $\mathrm{AC} / \mathrm{BC}$ & Laston & $\mathrm{AC} / \mathrm{BC}$ \\
\hline & Base & $\begin{array}{c}\text { Batu pecah kelas } \\
\text { A }\end{array}$ & Crushed Stone & $\begin{array}{l}\text { Agregat } \\
\text { kelas B }\end{array}$ & B Batu pecah kelas A & AC Base \\
\hline & Subbase & Sirtu Kelas B & Limestone & Tanah Urug & Sirtu Kelas B & LPB Kelas A \\
\hline \multicolumn{2}{|c|}{ Kelas Jalan } & I & I & I & I & I \\
\hline Modulus & Surface & 3500 & 3500 & 3500 & 3500 & 3500 \\
\hline Elastisitas & Base & 500 & 500 & 500 & 500 & 500 \\
\hline $\begin{array}{c}\text { Material } \\
\text { Perkerasan }\end{array}$ & Subbase & 100 & 100 & 100 & 100 & 100 \\
\hline $\begin{array}{l}\text { (Dalam } \\
\text { MPa) }\end{array}$ & Subgrade & 80 & 80 & 80 & 80 & 80 \\
\hline Modulus & Surface & 507633 & 507633 & 507633 & 507633 & 507633 \\
\hline Elastisitas & Base & 72519 & 72519 & 72519 & 72519 & 72519 \\
\hline $\begin{array}{l}\text { Material } \\
\text { Perkerasan }\end{array}$ & Subbase & 14503.8 & 14503.8 & 14503.8 & 14503.8 & 14503.8 \\
\hline $\begin{array}{l}\text { Perkerasan } \\
\text { (Dalam Psi) }\end{array}$ & Subgrade & 11603.04 & 11603.04 & 11603.04 & 11603.04 & 11603.04 \\
\hline \multicolumn{2}{|c|}{$\begin{array}{c}\text { Total Tebal Perkerasan } \\
\text { (Dalam } \mathrm{cm})\end{array}$} & 85 & 75 & 52.65 & 64 & 31.5 \\
\hline \multicolumn{2}{|c|}{$\begin{array}{c}\text { Total Tebal Perkerasan } \\
\text { (Dalam inch) }\end{array}$} & 33,4645672 & 29,527559 & 20,728347 & 25,196851 & 12,401575 \\
\hline
\end{tabular}

Data - data di atas, kemudian dianalisis dengan teori sistem lapis banyak yang terdiri dari teori one-layer system, two -layers system dan three-layers system. Berikut ini adalah hasil dari perhitungan dengan metode one layer systems, dimana tegangan dan regangan yang terjadi pada subgrade dihitung dengan rumus (2) dan (3).

Tabel 2. Perhitungan regangan dan tegangan pada subgrade dengan teori one layer systems

\begin{tabular}{|c|c|c|c|c|c|}
\hline Parameter & $\begin{array}{c}\text { Jalan A } \\
\text { (Oetomo,2013) }\end{array}$ & $\begin{array}{c}\text { Jalan B } \\
\text { (Hariyadi dan } \\
\text { Rulhendri ,2013) }\end{array}$ & $\begin{array}{c}\text { Jalan C } \\
\text { (Shalahuddin) }\end{array}$ & $\begin{array}{c}\text { Jalan D } \\
\text { (Nurahmi,2013) }\end{array}$ & $\begin{array}{c}\text { Jalan E } \\
(\text { Salim,2020) }\end{array}$ \\
\hline Ketebalan & & & & & \\
\hline $\begin{array}{l}\text { Perkerasan Total } \\
\text { (z) dalam m } \\
\text { Modulus }\end{array}$ & 0,85 & 0,75 & 0,5265 & 0,64 & 0,315 \\
\hline $\begin{array}{c}\text { Perkerasan }(\mathrm{E}) \\
\text { dalam } \mathrm{MPa}\end{array}$ & 89582,294 & 165343,32 & 75962,447 & 132800,42 & 169211 \\
\hline $\begin{array}{c}\text { Besaran beban } \\
\text { roda kendaraan } \\
(\mathrm{MPa})\end{array}$ & & & 0,689476 & & \\
\hline Angka Poisson & & & 0,3 & & \\
\hline $\begin{array}{c}\text { Luas Kontak (a) } \\
\text { dalam m }\end{array}$ & & & 0,150456 & & \\
\hline
\end{tabular}


Lanjutan Tabel 2. Perhitungan regangan dan tegangan pada subgrade dengan teori one layer systems

\begin{tabular}{|c|c|c|c|c|c|}
\hline Parameter & $\begin{array}{c}\text { Jalan A } \\
\text { (Oetomo,2013) }\end{array}$ & $\begin{array}{c}\text { Jalan B } \\
\text { (Hariyadi dan } \\
\text { Rulhendri ,2013) }\end{array}$ & $\begin{array}{c}\text { Jalan C } \\
\text { (Shalahuddin) }\end{array}$ & $\begin{array}{c}\text { Jalan D } \\
\text { (Nurahmi,2013) }\end{array}$ & $\begin{array}{c}\text { Jalan E } \\
(\text { Salim,2020) }\end{array}$ \\
\hline Posisi r (m) & \multicolumn{5}{|c|}{0 (Karena di tengah titik berat roda) } \\
\hline Rasio r/a & & & 0 & & \\
\hline Rasio z/a & 5,649472 & 4,984828 & 3,499349 & 4,25372 & 2,09362 \\
\hline $\begin{array}{c}\text { Koefisien A Ahlvin dan } \\
\text { Foster }\end{array}$ & 0,156435 & 0,196288 & 0,4059 & 0,2725 & 0,10014 \\
\hline $\begin{array}{c}\text { Koefisien B Ahlvin dan } \\
\text { Foster }\end{array}$ & 0,30531 & 0,38107 & 0,7597 & 0,522325 & 0,10327 \\
\hline $\begin{array}{l}\text { Besaran tegangan } \\
\text { pada subgrade } \\
(\mathrm{kPa})\end{array}$ & 318,3621 & 398,0745 & 803,6532 & 548,0128 & 140,251 \\
\hline $\begin{array}{c}\text { Besaran regangan pada } \\
\text { subgrade } \\
\text { (Mikrostrain) }\end{array}$ & 533,86577 & 361,34557 & 1577,9876 & 618,01198 & 140,307 \\
\hline
\end{tabular}

Selanjutnya, Data - data yang ada di tabel 1 kemudian dianalisis dengan teori sistem lapis banyak dengan metode teori two-layers system. Tegangan yang terjadi pada subgrade dihitung dengan menggunakan grafik di gambar 2. Karena teori two-layers system tidak menjelaskan cara menghitung regangan, maka regangan dihitung dengan menggunakan persamaan regangan dasar dimana regangan merupakan nilai rasio dari tegangan dan modulus elastisitas. Berikut ini adalah hasil dari perhitungan dengan metode two layer systems.

Tabel 3. Perhitungan regangan dan tegangan pada subgrade dengan teori two-layers systems

\begin{tabular}{|c|c|c|c|c|c|}
\hline Parameter & $\begin{array}{c}\text { Jalan A } \\
\text { (Oetomo, 2013) }\end{array}$ & $\begin{array}{c}\text { Jalan B } \\
\text { (Hariyadi dan } \\
\text { Rulhendri ,2013) } \\
\end{array}$ & $\begin{array}{c}\text { Jalan C } \\
\text { (Shalahuddin) }\end{array}$ & $\begin{array}{l}\text { Jalan D } \\
\text { (Nurahmi, } \\
\text { 2013) }\end{array}$ & $\begin{array}{c}\text { Jalan E } \\
\text { (Salim,2020) }\end{array}$ \\
\hline $\begin{array}{l}\text { Ketebalan Perkerasan } \\
\text { Total (z) dalam m }\end{array}$ & 0,85 & 0,75 & 0,5265 & 0,64 & 0,315 \\
\hline $\begin{array}{c}\text { Besaran beban roda } \\
\text { kendaraan }(\mathrm{MPa})\end{array}$ & \multicolumn{5}{|c|}{0,689476} \\
\hline Angka Poisson & \multicolumn{5}{|c|}{0,3} \\
\hline $\begin{array}{l}\text { Luas Kontak (a) dalam } \\
\text { m }\end{array}$ & \multicolumn{5}{|c|}{0,150456} \\
\hline Posisi r (m) & \multicolumn{5}{|c|}{0 (Karena di tengah titik berat roda) } \\
\hline Rasio r/a & \multicolumn{5}{|c|}{0} \\
\hline Rasio z/a & 5,649472 & 4,984828 & 3,499349 & 4,25372 & 2,09362 \\
\hline $\begin{array}{l}\text { E1 (Modulus elastisitas } \\
\text { Idealisasi Layer } \\
\text { Perkerasan, MPa) }\end{array}$ & 89582,294 & 165343,32 & 75962,447 & 132800,42 & 169211 \\
\hline $\begin{array}{l}\text { E2 (Modulus elastisitas } \\
\text { Tanah Subgrade, MPa) }\end{array}$ & 80 & 80 & 80 & 80 & 80 \\
\hline
\end{tabular}


Lanjutan Tabel 3. Perhitungan regangan dan tegangan pada subgrade dengan teori two-layers systems

\begin{tabular}{|c|c|c|c|c|c|}
\hline Parameter & $\begin{array}{c}\text { Jalan A } \\
(\text { Oetomo,2013) }\end{array}$ & $\begin{array}{c}\text { Jalan B } \\
\text { (Hariyadi dan } \\
\text { Rulhendri ,2013) }\end{array}$ & $\begin{array}{c}\text { Jalan C } \\
\text { (Shalahuddin) }\end{array}$ & $\begin{array}{c}\text { Jalan D } \\
\text { (Nurahmi, } \\
\text { 2013) }\end{array}$ & $\begin{array}{c}\text { Jalan E } \\
(\text { Salim,2020) }\end{array}$ \\
\hline \multicolumn{6}{|l|}{ Koefisien tegangan } \\
\hline $\begin{array}{c}\text { Burmister dari grafik } \\
\text { gambar }\end{array}$ & 1 & 0,9 & 1,1 & 0,975 & 1,25 \\
\hline $\begin{array}{l}\text { Besaran tegangan pada } \\
\text { subgrade }(\mathrm{kPa})\end{array}$ & 100 & 90 & 110 & 97,5 & 125 \\
\hline $\begin{array}{l}\text { Besaran regangan pada } \\
\text { subgrade (Mikrostrain) }\end{array}$ & 1116,292 & 544,32196 & 1448,0839 & 734,18443 & 738,72266 \\
\hline
\end{tabular}

Kemudian, sebagai pembanding dilakukan analisis dengan teori three-layers system. Adapun langkah awal dari metode ini adalah diawali dengan menghitung parameter data $\mathrm{k} 1$, k2, a dan $\mathrm{H}$ yang akan dimasukkan ke dalam grafik Peattie untuk mencari faktor tegangan vertikal ZZR2 dan tabel tabulasi Jones untuk mencari faktor tegangan horizontal [ZZ2 - RR2] dan [ZZ2 - RR3]. Kemudian, tegangan vertikal dihitung dengan rumus (8) dan tegangan horizontal dihitung dengan rumus (10) dan (11). Nilai regangan diperoleh dari modifikasi persamaan (12), yang disesuaikan dengan posisi dimana regangan ditinjau, yaitu di posisi subgrade Berikut ini adalah hasil dari perhitungan dengan metode three layer systems.

Tabel 4. Perhitungan regangan dan tegangan pada subgrade dengan teori three-layers systems

\begin{tabular}{|c|c|c|c|c|c|c|}
\hline \multicolumn{2}{|c|}{ Parameter } & $\begin{array}{c}\text { Jalan A } \\
\text { (Oetomo,2013) }\end{array}$ & $\begin{array}{c}\text { Jalan B } \\
\text { (Hariyadi dan } \\
\text { Rulhendri } \\
\text {,2013) }\end{array}$ & $\begin{array}{c}\text { Jalan C } \\
\text { (Shalahuddin) }\end{array}$ & $\begin{array}{c}\text { Jalan D } \\
\text { (Nurahmi } \\
\text {,2013) }\end{array}$ & $\begin{array}{c}\text { Jalan E } \\
(\text { Salim,2020) }\end{array}$ \\
\hline Ketebalan & Surface & 10 & 20 & 5,75 & 13 & 9 \\
\hline \multirow{2}{*}{$\begin{array}{l}\text { Perkerasan } \\
\text { dalam } \mathrm{cm}\end{array}$} & Base & 25 & 25 & 6,9 & 20 & 7,5 \\
\hline & Subbase & 50 & 30 & 40 & 31 & 15 \\
\hline \multicolumn{2}{|c|}{$\mathrm{p}($ Dalam kPa $)$} & & & 689,476 & & \\
\hline \multicolumn{2}{|c|}{ a (Dalam m) } & & & 0,150456456 & & \\
\hline \multicolumn{2}{|c|}{ Tebal h1 (Dalam m) } & 0,1 & 0,2 & 0,0575 & 0,13 & 0,09 \\
\hline \multicolumn{2}{|c|}{ Tebal h2 (Dalam m) } & 0,75 & 0,55 & 0,469 & 0,51 & 0,225 \\
\hline \multirow[t]{2}{*}{$\begin{array}{l}\text { Idealsasi } \\
\text { Modulus }\end{array}$} & Surface & & & 3500 & & \\
\hline & Base & 233,333847 & 281,8188 & 158,84896 & 256,86331 & 233,33385 \\
\hline \multirow{2}{*}{\multicolumn{2}{|c|}{$\begin{array}{l}\text { Elastisitas } \\
\text { (Dalam MPa) } \\
\text { Faktor k1 }\end{array}$}} & & & 80 & & \\
\hline & & 15 & 12,419355 & 22,033557 & 13,625954 & 15 \\
\hline \multicolumn{2}{|c|}{ Faktor k2 } & 2,91666667 & 3,5227273 & 1,9856077 & 3,2107843 & 2,9166667 \\
\hline \multicolumn{2}{|c|}{ Faktor a1 } & 0,20060872 & 0,2735573 & 0,3208029 & 0,2950128 & 0,6686957 \\
\hline \multicolumn{2}{|c|}{ Faktor H } & 0,13333333 & 0,3636364 & 0,1226013 & 0,254902 & 0,4 \\
\hline \multicolumn{2}{|c|}{ Faktor ZZ2 } & 0,023 & 0,027 & 0,065 & 0,038 & 0,105 \\
\hline \multicolumn{2}{|c|}{ Faktor ZZ2-RR2 } & 0,063166 & 0,038335 & 0,029012 & 0,1054439 & 0,3086177 \\
\hline \multicolumn{2}{|c|}{ Faktor ZZ2-RR3 } & 0,029012 & 0,13048 & 0,077569 & 0,0465438 & 0,1346064 \\
\hline
\end{tabular}


Lanjutan Tabel 4. Perhitungan regangan dan tegangan pada subgrade dengan teori three-layers systems

\begin{tabular}{cccccc}
\hline Parameter & Jalan A & $\begin{array}{c}\text { Jalan B } \\
\text { (Hariyadi } \\
\text { dan } \\
\text { Rulhendri, } \\
\text { 2013) }\end{array}$ & $\begin{array}{c}\text { Jalan C } \\
\text { (Shalahuddin) }\end{array}$ & $\begin{array}{c}\text { Jalan D } \\
\text { (Nurahmi } \\
, 2013)\end{array}$ & $\begin{array}{c}\text { Jalan E } \\
\text { (Salim,2020) }\end{array}$ \\
\hline $\begin{array}{c}\text { Tegangan Vertikal Pada Titik } \\
\text { Subgrade (Dalam kPa) }\end{array}$ & 15,857948 & 18,615852 & 44,81594 & 26,200088 & 72,39498 \\
$\begin{array}{c}\text { Tegangan Horizontal Pada Titik } \\
\text { Base dan Subbase (Dalam kPa) }\end{array}$ & $-27,693493$ & $-71,346976$ & $-60,624246$ & $-46,50098$ & $-140,38949$ \\
$\begin{array}{c}\text { Tegangan Horizontal Pada Titik } \\
\text { Subgrade (Dalam kPa) } \\
\text { Regangan Pada Subgrade } \\
\text { (Dalam mikrostrain) }\end{array}$ & $-4,14512971$ & $-4,07894$ & $-8,6660238$ & $-5,8907255$ & $-20,412876$ \\
\hline
\end{tabular}

Berdasarkan perhitungan - perhitungan yang telah dilakukan di atas, bisa dibuat mengenai tabel - tabel yang membandingkan antara hasil perhitungan dari Jalan A (Oetomo, 2013), Jalan B (Hariyadi dan Rulhendri, 2013), Jalan C (Shalahuddin), Jalan D (Nurahmi, 2013) dan Jalan E (Salim, 2020). Dari tabel di atas, nilai perbandingan ketebalan dan regangan pada subgrade bisa disajikan pula ke dalam grafik, sehingga termuat grafik seperti di bawah.

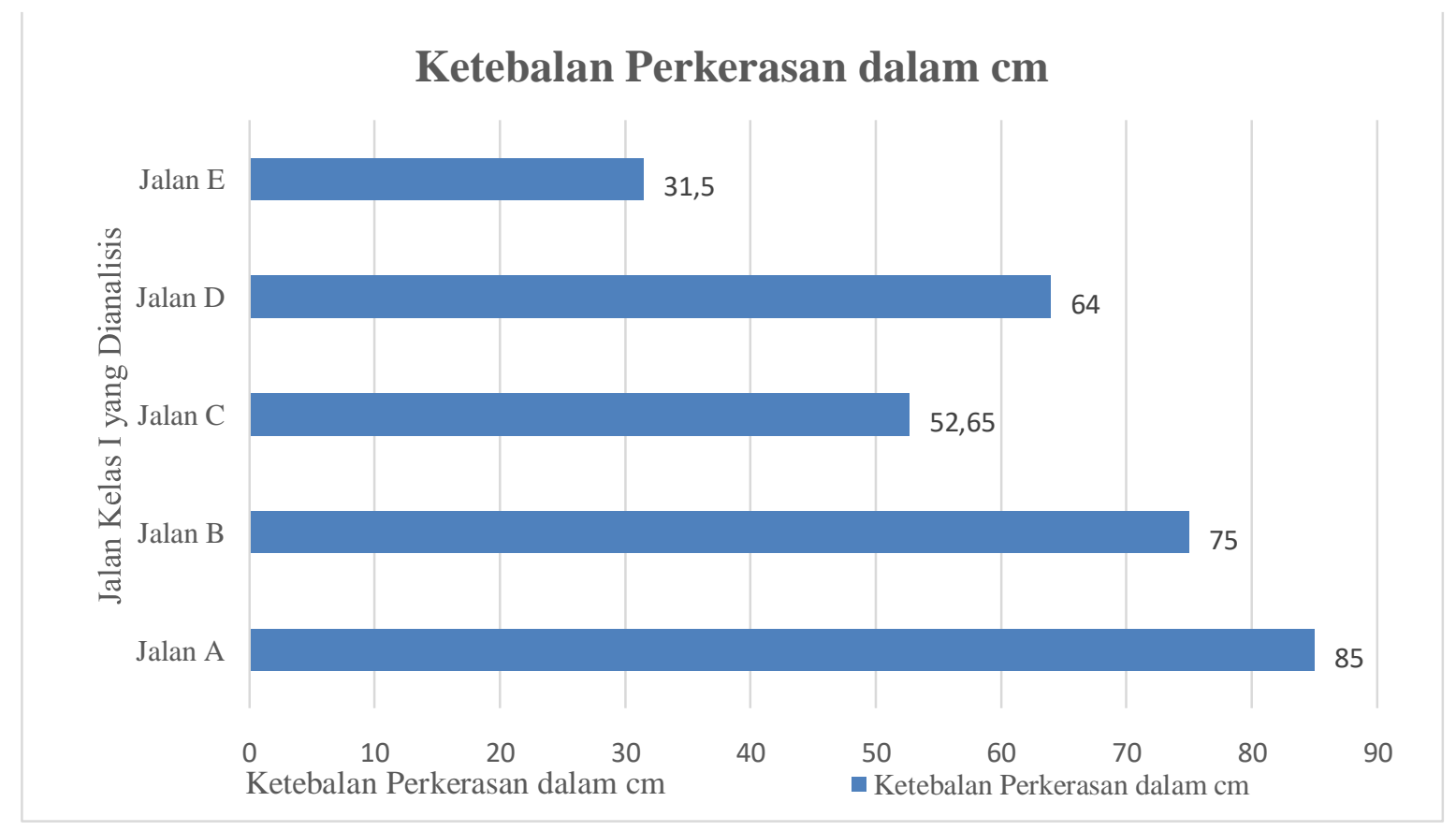

Gambar 3. Ilustrasi perbandingan ketebalan perekrasan jalan yang dianalisis dengan teori multi-layered systems

Dari grafik di atas, ketebalan jalan berkisar nilainya antara $31.5 \mathrm{~cm}$ hingga $85 \mathrm{~cm}$. Adapun bisa dilihat bahwa nilai jalan E (Salim, 2020) merupakan jalan dengan perkerasan tertipis, sedangkan jalan A (Oetomo, 2013) merupakan jalan dengan perkerasan tertebal. Adapun mengenai nilai yang dihasilkan dari regangan - regangan dengan multilayered systems theory dimuat di halaman berikutnya. 


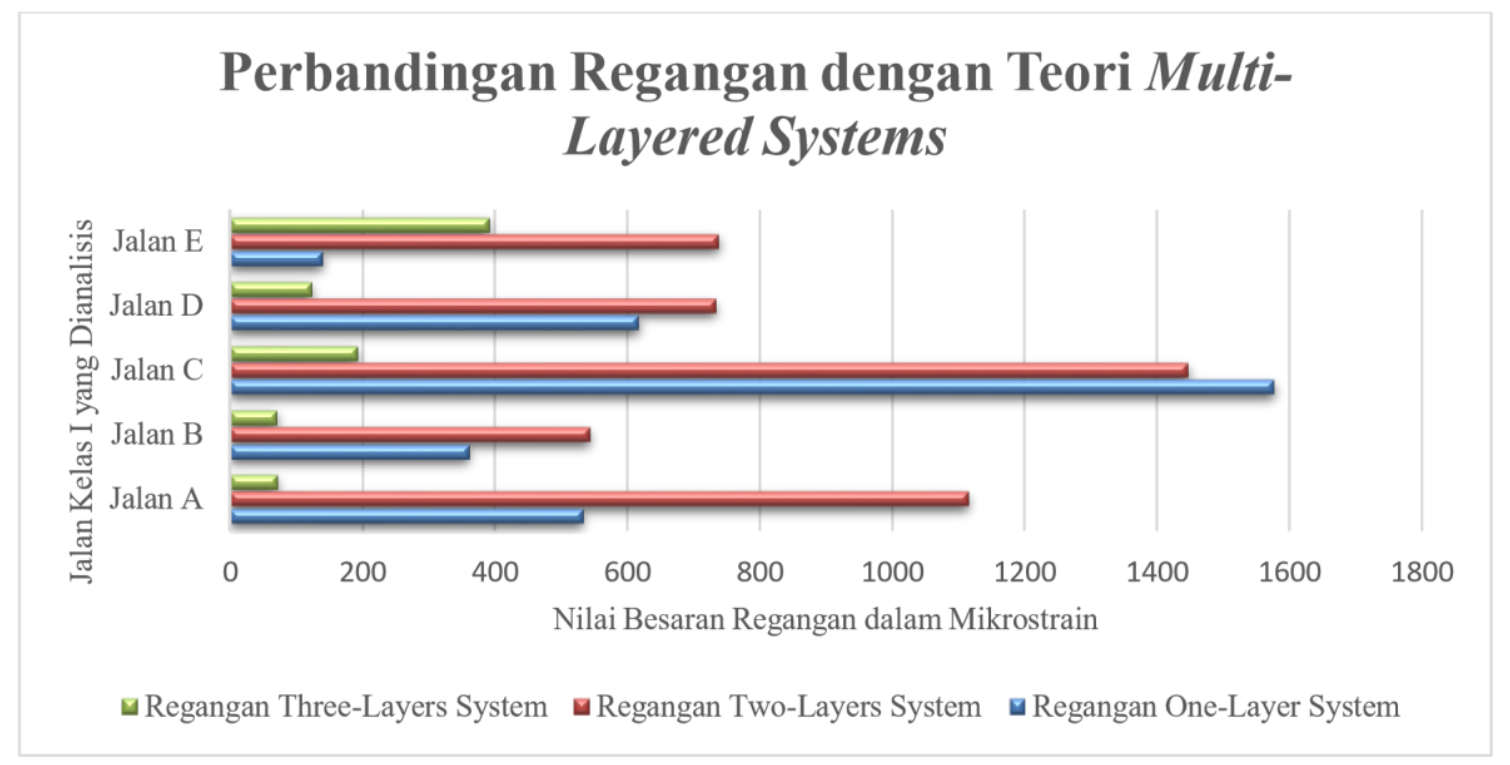

Gambar 4. Ilustrasi perbandingan perhitungan regangan dengan teori multi-layered systems

Dari grafik di atas, kita bisa melihat bahwa besarn regangan dengan teori one-layer system nilainya berkisar mulai dari 140 mikrostrain hingga 1500 mikrostrain. Untuk jalan dengan teori two-layers system, nilai regangan yang diperoleh besarnya antara lain 734 mikrostrain hingga 1448 mikrostrain. Adapun jalan yang dianalisis dengan teori three-layers system, nilai regangannya berkisar dari 70 mikrostrain hingga 391 mikrostrain.

Parameter data yang sangat mempengaruhi hasil dari studi perbandingan ini adalah modulus elastisitas dari material perkerasan, serta ketebalan desain dari perkerasan jalan. Dari hasil perhitungan di atas, nilai yang diperoleh dengan perhitungan dengan metode two-layers system memiliki hasil yang paling besar jika dibandingkan dengan metode perhitungan lainnya, diikuti dengan metode one-layer system dan yang terkecil dihasilkan oleh metode three-layers system.

Nilai yang dihasilkan oleh metode two-layers system jauh lebih besar jika dibandingkan kedua metode lainnya, disebabkan karena keterbatasan teori untuk mencari nilai regangan, dimana teori ini juga merupakan pengembangan dari teori one-layer system. Adapun teori two-layers system hanya membatasi nilai maksimum untuk rasio ketebalan perkerasan dengan luas kontak ban hanya mencapai nilai 3. Selain itu, belum adanya pengembangan lebih lanjut untuk mencari rumus regangan juga menjadi kekurangan teori ini. Oleh sebab itu, penulis mencari regangan dengan teori ini menggunakan persamaan dasar, dimana regangan merupakan rasio dari tegangan dan modulus elastisitas.

Adapun regangan yang dihasilkan dari teori one-layer systems merupakan nilai regangan kedua terbesar. Teori ini merupakan teori yang paling banyak dikembangkan, mulai dari penelitian Bousinessq hingga Ahlvin dan Foster. Adapun keterbatasan ini menganggap bahwa lapisan di posisi subgrade tidak ditinjau alias diabaikan, sehingga nilai dari parameter modulus elastisitas pada tanah dasar ini tidak berpengaruh apa - apa terhadap besaran regangan. Namun, dibandingkan teori two-layers systems, teori ini lebih lengkap karena menyertakan persamaan regangan dan tegangan pada perkerasan, bahkan tidak hanya dalam posisi vertikal saja, melainkan posisi radial dan tangensial.

Nilai regangan yang dihasilkan dengan teori three-layers system merupakan nilai regangan yang terkecil jika dibandingkan dengan kedua teori sebelumnya. Keunggulan dari teori ini adalah teori ini memperhitungkan adanya keberadaan dari lapisan subgrade atau tanah dasar. Selain itu, teori ini juga membagi lapisan yang ditinjau ke dalam tiga lapisan, yaitu lapisan aspal atau lapisan permukaan, lapisan agregat dan tanah dasar. Berbeda dengan teori onelayer system dan two-layers system yang mengidealisasikan tiga lapisan perkerasan lentur menjadi satu lapisan.

Jika dibandingkan dengan penelitian terdahulu, nilai perhitungan regangan jalan $\mathrm{A}, \mathrm{B}, \mathrm{C}$ dan $\mathrm{D}$ dengan teori threelayers system masuk dalam kriteria batas untuk nilai regangan pada subgrade, yaitu sebesar 72.2028; 70.8035; 192.9638 dan 123.115. Jalan A, B, C dan D memiliki nilai regangan subgrade yang lebih kecil daripada 200 mikrostrain, sehingga dapat dikatakan Jalan A, B, C dan D aman dari kerusakan alur (rutting) struktural. Hanya ada satu jalan yang regangannya melebihi 200 mikrostrain, yaitu Jalan E sebesar 391.8846 mikrostrain. Hal ini disebabkan oleh ketebalan perkerasan yang jauh lebih tipis jika dibandingkan dengan jalan A, B, C dan D yang ketebalannya hampir mendekati satu sama lain. 
Berdasarkan hal diatas, tentunya nilai regangan yang paling ideal merupakan nilai yang dihasilkan melalui perhitungan dengan three-layers systems, dimana regangan jauh lebih kecil daripada 200 mikrostrain. Sehingga, untuk menganalisis regangan jalan kelas I di Indonesia sebaiknya idealnya menggunakan teori three-layers systems.

\section{KESIMPULAN DAN SARAN}

\section{Kesimpulan}

Berdasarkan penelitian yang telah dilakukan dapat disimpulkan sebagai berikut:

1. Berdasarkan analisis dengan metode multi - layered systems, diperoleh hasil yang berbeda - beda terkait dengan besaran regangan yang diperoleh. Hal ini menunjukkan bahwa pengaplikasian teori berbeda dikarenakan nilai dari modulus elastisitas yang berubah-ubah, sesuai dengan idealisasi teori.

2. Berdasarkan analisis dengan metode multi - layered systems, nilai dari regangan dan tegangan sangat bergantung dengan parameter modulus elastisitas dan ketebalan dari perkerasan.

3. Teori three-layers system merupakan teori yang ideal dalam menghitung besaran regangan, dikarenakan pembagian lapisan yang cukup banyak dan meninjau juga pengaruh dari tanah dasar. Sehingga, besaran regangan yang dihasilkan ideal dan masih memenuhi.

4. Jalan A, B, C dan D memenuhi kriteria desain dan keawetan dikarenakan regangan yang dihasilkan dibawah dari regangan batas antara lain 72,2027; 70,8035; 192,9638; dan 123.115 mikrostrain. Regangan tersebut masuk kriteria batas regangan, dimana nilainya lebih kecil dari 200 mikrostrain, yang mengacu pada penelitian Monismith et al. (2004), Walubita et al. (2008) dan Prowell (2010).

\section{Saran}

Berdasarkan analisis dan perhitungan yang sudah dilakukan, adapun terdapat beberapa saran yang bisa diperhatikan untuk melakukan analisis lebih lanjut, akurat dan mendalam terkait dengan studi regangan yang terjadi pada jalan raya berperkerasan lentur kelas I di Indonesia. Adapun saran - saran tersebut antara lain sebagai berikut:

1. Penelitian ini bisa dikembangkan dengan cara memodifikasi parameter lapisan subgrade, sehingga bisa mengetahui jenis lapisan subgrade yang baik untuk perkerasanjalan. Selain itu, penelitian ini juga bisa dikembangkan dengan menggunakan parameter CBR untuk tanah dasar.

2. Studi perbandingan dengan teori multi-layered systems ini memiliki hasil yang sangat bergantung dan sensitif terhadap nilai dari parameter modulus elastisitas, sehingga untuk memperoleh data modulus elastisitas yang lebih akurat dapat dilakukan dengan uji atau test laboratorium.

3. Untuk memperoleh hasil yang lebih akurat dan tepat sebagai pembanding, hasil perhitungan dengan teori teori konvensional dapat dianalisis dengan metode lain, seperti dengan penggunaan program berbasis metode elemen hingga (Finite element method) seperti PLAXIS ataupun MIDAS GTX untuk memperoleh nilai regangan sebagai pembanding lain, yang dimana permodelannya dikondisikan sesuai dengan kondisi perhitungan konvensional.

\section{DAFTAR PUSTAKA}

Bejarano, M.O. dan M. R. Thompson. "Subgrade Damage Approach for the Design of Airport Flexible Pavements." Proceedings of the 2001 Airfield Pavement Speciality Conference: Advancing Airfield Pavements. Washington D.C.: American Society of Civil Engineers, 2001. 44-58.

Hardiyatmo, Hary Christady. Perancangan Perkerasan Jalan dan Penyelidikan Tanah. Yogyakarta: Gadjah Mada University Press, 2011.

Hariyadi, Eri Susanto dan Rulhendri. "Pengaruh Jenis Pembebanan Dalam Analisis Struktur Perkerasan Lentur Terhadap Kinerja Perkerasan." Jurnal Rekayasa Sipil ASTONJADRO (2013): 49-57.

Jackson, N., J. Mahoney and J. Puccinelli. "Using Existing Pavement in Place and Achieving Long Life." Final Report, SHRP 2 R23 TRB (2012).

Monismith, C dan McLean D. "Structural Design Considerations." Proceedings of the Association of Ashpalt Paving Technologist (1972): Vol. 41.

Monismith, C, et al. "The I-710 Freeway Rehabilitation Project; Mix and Structural Section Design, Construction Considerations and Lessons Learned." International Symposium on Design and Construction of Long Lasting Ashpalt Pavements. Auburn, AL: National Center for Ashpalt Technology, 2004. 217-262.

Nurahmi, Oktodelina dan Anak Agung Gde Kartika. "Perbandingan Konstruksi Perkerasan Lentur dan Perkerasan Kaku serta Analisis Ekonominya pada Proyek Pembangunan Jalan Lingkar Mojoagung." Jurnal Teknik ITS Vol. 1 (2012): 63-68. 
Oetomo, Wateno. "Alternatif Lain Analisis Struktur Jalan Perkerasan Lentur Pada Pembangunan Jalan Lingkar Selatan Kota Pasuruan." Extrapolasi Jurnal Teknik Sipil Untag Surabaya (2013): 118-136.

Prowell, B, et al. "Validating the Fatigue Endurance Limit for Hot Mix Ashpalt." 2010.

Salim, Abdul Kadir dan Harun Wibisono Muhammad Akhyar Darmawan. "Analisa Perbandingan Biaya Perkerasan Kaku dan Perkerasan Lentur Pada Proyek Jalan Middle Ring Road Kota Makassar." Jurnal Teknik Sipil MACCA (2020): 41-47.

Sentosa, S. Gregorius, A. Prihatiningsih dan D. Kosasih. "Uji Desak Bebas terhadap Material Tanah untuk Mengevaluasi Batas-batas Kinerja untuk Struktur Perkerasan Jalan yang Memiliki Ketahanan 50 Tahun." Laporan Akhir Penelitian Hibah Bersaing Tahun Anggaran 2014 Kemenristekdikti (2014). Lembaga Penelitian dan Publikasi Ilmiah Universitas Tarumanagara, Jakarta.

Shalahuddin, Muhammad. "Analisa Kegagalan Kualitas dan Kuantitas Perkerasan Lentur." Jurnal Fakultas Teknik Universitas Pasir Pengaraian (n.d.): 7-17.

Sukirman, Silvia. Perkerasan Lentur Jalan Raya. Bandung: Nova, 1999.

Undang - Undang Nomor 22 Tahun 2009 Tentang Lalu Lintas dan Angkutan Jalan. Jakarta: Departemen Perhubungan, 2009.

Walubita, L.F, et al. "Modeling Perpetual Pavements Using the Flexible Pavement System Software." Proceedings of the 87th Transportation Research Board Meeting. Washington D.C.: Transportation Research Board, 2008.

Yoder, M.W dan E.J Witczak. Principles of Pavement Design 2. New York: A Wiley-Interscience Publication, 1975. 